INTRODUCTION TO BRITISH GOVERNMENT 


\title{
INTRODUCTION TO BRITISH GOVERNMENT
}

\author{
S. G. Richards \\ Senior Lecturer in Government \\ Hammersmith and West London College
}

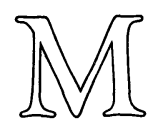


(C) S. G. Richards 1978

Softcover reprint of the hardcover 1 st edition 1978

All rights reserved. No part of this publication may be reproduced or transmitted, in any form or by any means, without permission.

\author{
First published 1978 by \\ THE MACMILLAN PRESS LTD \\ London and Basingstoke \\ Associated companies in Delhi Dublin \\ Hong Kong Johannesburg Lagos Melbourne \\ New York Singapore and Tokyo
}

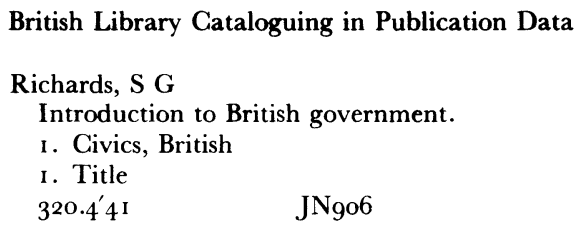

ISBN 978-o-333-23466-2 ISBN 978-1-349-15877-5 (eBook)
DOI 10.10o7/978-1-349-15877-5

This book is sold subject to the standard conditions of the Net Book Agreement.

The paperback edition of this book is sold subject to the condition that it shall not, by way of trade or otherwise, be lent, re-sold, hired out, or otherwise circulated without the publisher's prior consent in any form of binding or cover other than that in which it is published and without a similar condition including this condition being imposed on the subsequent purchaser. 
To W. A. M. 
... we should like to have good rulers, but historical experience shows us that we are not likely to get them. This is why it is of such importance to design institutions which prevent even bad rulers from causing too much damage.

Classes, however, never rule, any more than nations. The rulers are always certain persons. And, whatever class they may have once belonged to, once they are rulers they belong to the ruling class.

SIR KARL POPPER

Conjectures and Refutations, 1976 


\section{Contents}

Preface $\quad$ ix

Acknowledgements $\quad$ x

I The Nature of Politics and Government I

2 Constitutions I I

3 The Electoral System $\quad 20$

4 The Party System 43

5 Parliament: The House of Commons - I 53

6 Parliament: The House of Commons - II 67

7 The Monarchy and the House of Lords 77

8 The Cabinet and the Prime Minister 85

9 Pressure Groups $\quad 96$

Io The Civil Service and Government Departments 105

I I The English Legal System I 9

I 2 The Public Corporations I43

I 3 Local Government I - Structure and Functions I54

I4 Local Government II - Management I 7 I

I5 Local Government III - Finance $\quad$ I88

I6 Britain and the European Economic Community 204

I 7 Devolution 2 I 2

I8 Postscript: Some Reflections on the Prospects for British Government $22 \mathrm{I}$

Notes and References $\quad 228$

Index $\quad 235$

GARtoon: from Punch, 3 November i 965 (Reproduced by courtesy of Punch Publications Ltd) 


\section{Preface}

This book is intended as an introduction to the intricacies of the British system of government. It is directed mainly at those who are preparing for the Ordinary National Certificate in Public Administration and for its successor qualification administered by the Business Education Council; but it will also be suitable for the Government and Public Administration papers of the Rating and Valuation Association, the Institute of Housing, the Incorporated Society of Valuers and Auctioneers, the Chartered Institute of Public Finance and Accountancy, various other professional bodies and for the Advanced-Level GCE papers in British Government and Political System.

The general reader may well find the book of interest.

Local government has been dealt with in somewhat greater detail than in comparable books.

I would like to record my thanks to Professor Hugh Berrington, Head of the Department of Politics at the University of Newcastle upon Tyne, for his generous help and encouragement. The shortcomings of the book are entirely mine.

At the end of each chapter is given a list of books which deal in greater detail with the particular subject matter of the chapter. The following books give a comprehensive treatment of British government:

R. M. Punnett, British Government and Politics (Heinemann, 3rd edn, I976).

P. J. Madgwick, Introduction to British Politics (Hutchinson, 2nd edn, 1976).

I. Gilmour, The Body Politic (Hutchinson, 1971).

April 1977

S. G. R. 


\section{Acknowledgements}

The author and publishers wish to thank the following who have kindly given permission for the use of copyright material:

George Allen \& Unwin (Publishers) Limited for extract from Political Representation and Elections in Britain by P. G. J. Pulzer.

The Economist Newspaper Limited for an extract from The Economist, 13.9.75.

David Higham Associates Limited for extract from In Place of Fear by Aneurin Bevan, published by E.P. Publishing Limited.

Hutchinson Publishing Group Limited for extract from The Body Politic by Ian Gilmour.

H.M.S.O. for extracts from Fulton Report on the Civil Service, Cmnd ${ }_{36} 6{ }_{3}$, A Study of U.K. Nationalised Industries and a table based on official statistics relative to the estimated yield of major taxes in the U.K. $1975-6$.

New Science Publications for a diagram 'The Eclipse of Fulton' by G. W. Jones from New Society, I 7.8.72, London, the Weekly Review of the Social Sciences.

The Observer Limited for extracts by John Mackintosh from The Observer, 21.8.66, and Arnold Toynbee from The Observer, 25.10.75.

Penguin Books Limited for extract from Constitutional and Administrative Law, 2nd edition, 1973, by S. A. de Smith.

The Rt Hon.J. Enoch Powell, M.B.E., M.P., for an extract from the introduction of his book Great Parliamentary Occasions, published by Barrie \& Jenkins.

Routledge \& Kegan Paul Limited and Professor Sir Karl Popper for extracts from his book Conjectures and Refutations (London, 1963, 6th impression 1976, pp. 344 and 345. New York: Basic Books, 1962; and New York: Harper Torch Books, I968).

Times Newspapers Limited for a table from The Times Guide to the House of Commons. 